\title{
MARKET SEGMENT EVALUATION AND SELECTION BASED ON APPLICATION OF FUZZY AHP AND COPRAS-G METHODS
}

\author{
Mohammad Hasan Aghdaie ${ }^{1}$, Sarfaraz Hashemkhani Zolfani ${ }^{2}$, \\ Edmundas Kazimieras Zavadskas ${ }^{3}$
}

\author{
1,2 Department of Industrial Engineering, Shomal University, P.O. Box 731, \\ Amol, Mazandaran, Iran \\ 1, 2, 3 Institute of Internet and Intelligent Technologies, Vilnius Gediminas Technical University, \\ Sauletekio al. 11, 10223 Vilnius, Lithuania \\ E-mails: 1'mh_aghdaie@yahoo.com; ${ }^{2}$ sa.hashemkhani@gmail.com; \\ 3edmundas.zavadskas@vgtu.lt (correspondingauthor) \\ Received 02 February 2012; accepted 13 August 2012
}

\begin{abstract}
Market segment evaluation and selection is one of the critical marketing problems of all companies. This paper presents a novel approach which integrates fuzzy analytic hierarchy process (FAHP) and COPRAS-G method for market segment evaluation and selection. Fuzzy AHP is used to calculate the weight of each criterion, and COPRAS$\mathrm{G}$ method is proposed to prioritize market segments from the best to the worst ones. The application of fuzzy set theory allows incorporating the vague and imprecise linguistic terms into the decision process. This study can be used as a pattern for market segment selection and future researches. A case study on a chair manufacturing company is put forward to illustrate the performance of the proposed methodology.
\end{abstract}

Keywords: market segmentation, market segment evaluation, market segment selection, Fuzzy AHP, COPRAS-G method.

Reference to this paper should be made as follows: Aghdaie, M. H.; Hashemkhani Zolfani, S.; Zavadskas, E. K. 2013. Market segment evaluation and selection based on application of fuzzy AHP and Copras-G methods, Journal of Business Economics and Management 14(1): 213-233.

JEL Classification: C02, C44, D40, D46, D81.

\section{Introduction}

Market segmentation becomes an essential element of marketing in industrialized countries and in living of any business (Wedel, Kamakura 2000). Market segmentation is defined as the partitioning of a market into distinct subsets of customers and any subset could be possibly selected as a target market to be reached with a distinct marketing mix (Kotler 1999). In other words, market segmentation makes it possible to find homogeneous smaller markets by this means, helping marketers to recognize marketing opportunities and to develop products and services in a more tailor-made manner (Jang et al. 2002). 
Although market segmentation was introduced into the academic marketing literature by Smith (1956), market segmentation continues to be an important focal point of ongoing research and marketing practices (Chaturvedi et al. 1997; Hanafizadeh, Mirzazadeh 2011). Maybe mass marketing will no longer exist in the coming century or it will become vanished (Kuo et al. 2002). There are a lot of advantages of market segmentation over mass marketing. Firstly, it repeatedly helps every company to find a good chance to expand its own market by better satisfying the wants of customers. Secondly, it increases the profitability or effectiveness of the organization to the extent that the economic benefits provided for consumers exceed the costs of the segmentation process (Chiu et al. 2009). Thirdly, the importance of doing marketing segmentation analysis includes better perception of the market to truly position of a product in the marketplace, choosing the appropriate segments for target marketing, discovering opportunities in existing markets, and gaining competitive advantage through product differentiation (Kotler 1980).

There are many market segmentation bases in the literature that were used to divide a market into segments such as geographic, demographic, life style and product benefits (Kazemzadeh et al. 2009). Besides, there are numerous market segmentation methods such as factor analysis, clustering, conjoint, regression, and discriminate analysis. Also recently, using or integrating other fields including data mining, multivariate statistical analysis, fuzzy logic, artificial neural networks, and genetic algorithm becomes a common tool for market segmentation.

After market segmentation, every company needs to evaluate and select target market or markets, and then Market segmentation evaluation is a critical management decision because all other components of a marketing strategy follow it (Wind, Thomas 1994). Also, Market segment evaluation can help in targeting markets, thus it is very important for improving the probability of success in competitive market.

Although much of the marketing literature has proposed various market segmentation techniques, but a review of academic research reveals that existing studies have relatively neglected segment evaluation and selection (Sarabia 1996; Ou et al. 2009). Also most existing studies suggest some general criteria for evaluation of attractiveness of a segment and merely present a model or method for evaluation.

Selecting an appropriate market segment based on evaluation of segments is one of the most complicated and time consuming problems for many companies, due to many feasible alternatives, conflicting objectives and variety of factors (Aghdaie et al. 2011). Market segment evaluation and selection decisions are sophisticated by the fact that the decision-making process must consider various criteria. Therefore market segment evaluation and selection can be viewed as a multiple criteria decision- making (MCDM) problem. Hence, this study has the main objective of proposing a mechanism for market segment evaluation and selection.

The MCDM methods deal with the process of making decisions for finding the optimum alternative in the presence of multiple, usually conflicting, decision criteria.

In this research a hybrid MCDM model encompassing fuzzy analytic hierarchy process (FAHP) and the complex proportional assessment of alternatives with grey relations 
(COPRAS-G method) are used for market segment evaluation and selection. Specifically, FAHP is initially used for calculating the weight of each criterion and COPRAS-G method is used for ranking and selecting the best location.

The remainder of this paper is organized as follows. The related studies are summarized in Section 2. The third section presents the methodology including FAHP and COPRAS$\mathrm{G}$ method. In Section 4, a real-world case study is given to prove the applicability of the proposed method on a large- sized manufacturing enterprise in Iran. In Section 4, the results are discussed. In Section 5, finally, the article will be concluded.

\section{Literature review}

Market segment evaluation and selection is one of the important problems for every company. The major part of the related literature concentrates on the important features for doing this evaluation and very little research has been done on the evaluation of segment attractiveness and market segment selection. The enormous majority of decisionmaking methods identified apply to the final stage of market segment evaluation and selection. Also, it is remarkable that segmentation itself has many limitations in terms of product, segment size, profitability/yield, attainability with promotion mix and supply, doubled expenses for marketing mix, industry, etc. Generally, expert efforts have focused on evaluating different segmentation methods and techniques (Bonoma, Shapiro 1983; Christen 1987; Elrod, Winner 1982; Morrison 1973; Novak et al. 1992; Wildt 1976). Even general studies of market segmentation have paid little or no attention to the evaluation and selection stages (Beane, Ennis 1987; Weinstein 1987; Wind 1978). Authors generally limit themselves to analyzing how to evaluate segment stability (Bettman 1971; Calentone, Sawyer 1978; Lehmann et al. 1982; MacLachlan, Johansson 1981), congruence (Green 1977), internal homogeneity and profitability (Eckrich 1984; Van Auken, Lonial 1984; Beik, Buzby 1973), to mention only the most relevant.

Some general criteria such as identity ability, substantiality, accessibility, stability, responsiveness, action ability have been frequently put forward as determining the effectiveness and profitability of market segment (Frank et al. 1972; Loudon, Della Bitta 1984; Baker 1988; Kotler 1988). Based on research of the United Kingdom's Times Top 1000 companies, Simkin and Dibb (1998) found that the three most important factors for selecting target markets were profitability, market growth, and market size. McQueen and Miller (1985) recommended the assessment of market attractiveness based upon profitability, variability, and accessibility. In the same way, Loker and Perdue (1992) proposed a systematic approach to evaluating segments using a ranking procedure. They assessed segment attractiveness in terms of profitability, accessibility, and reachability by ranking each segment on its relative performance according to the three evaluation criteria. Based on Kotler and Armstrong (2003) the market segments should meet five selection criteria including: (1) measurable, (2) accessible, (3) sustainable, (4) differentiable, and (5) actionable to be viable. Also, Morrison (2002) added five more criteria in Kotler and Armstrong's list for effective segmentation, including: homogeneity, defensibility, competitiveness, durability, and compatibility. These theoretically fundamental 
criteria provide marketers with useful guidelines for targeting markets (Lee et al. 2006). Bock and Uncles (2002) suggested that, when preparing a segmentation strategy, profitability must be considered as one of the main selection criteria. Jang et al. (2002) incorporated the profitability and risk concepts in evaluating segment attractiveness as more quantifiable and comprehensive profitability measures. Most of these studies, propose different schemes for market segmentation, however, they have concentrated on evaluation and therefore have only taken into account very specific criteria. Ou et al. (2009) incorporated the famous model that was developed by Porter (1980) to evaluate each potential segment. Companies must carefully assess and weigh key discriminating criteria to find the "best" market segments (Weinstein 2004).

McDonald and Dunbar (2004) prepared one of the comprehensive criteria list for market segment evaluation. They also provide a list of twenty-seven possible, generalized segment attractiveness factors in five major areas: segment factors, competition, financial and economic factors, technology, and sociopolitical factors. McDonald and Dunbar add segment attractiveness factors be weighted based on the particular requirements of an organization.

This study uses the McDonald and Dunbar's (2004) criteria list as the basis for market segment evaluation. This criteria list is depicted in Table 1.

Table 1. The segment attractiveness criteria

\begin{tabular}{|c|c|}
\hline Criteria & Sub-criteria \\
\hline \multirow[t]{7}{*}{ Segment factors } & Size (money, units or both) \\
\hline & Growth rate per year \\
\hline & Sensitivity to price, service features and external factors \\
\hline & Cyclicality \\
\hline & Seasonality \\
\hline & Bargaining power of upstream suppliers \\
\hline & Bargaining power of downstream suppliers \\
\hline \multirow[t]{7}{*}{ Competition } & Types of competitors \\
\hline & Degree of concentration \\
\hline & Changes in type and mix \\
\hline & Entries and exits \\
\hline & Changes in share \\
\hline & Substitution by new technology \\
\hline & Degrees and types of integration \\
\hline \multirow[t]{2}{*}{ Financial and economic factors } & Contribution margins \\
\hline & $\begin{array}{l}\text { Leveraging factors, such as economies of scale } \\
\text { and experience }\end{array}$ \\
\hline
\end{tabular}


End of Table 1

\begin{tabular}{|c|c|}
\hline Criteria & Sub-criteria \\
\hline \multirow[t]{2}{*}{ Financial and economic factors } & Barriers to entry or exit (financial and non-financial) \\
\hline & Capacity utilization \\
\hline \multirow[t]{5}{*}{ Technological factors } & Maturity and volatility \\
\hline & Complexity \\
\hline & Differentiation \\
\hline & Patents and copyrights \\
\hline & Manufacturing process technology required \\
\hline \multirow[t]{4}{*}{ Socio-political factors } & Social attitudes and trends \\
\hline & Laws and government agency regulations \\
\hline & $\begin{array}{l}\text { Influence with pressure groups and government } \\
\text { representatives }\end{array}$ \\
\hline & $\begin{array}{l}\text { Human factors, such as unionization and community } \\
\text { acceptance }\end{array}$ \\
\hline
\end{tabular}

Source: adopted from McDonald and Dunbar (2004); modified from related research.

\section{Methodology}

Over the past decades the complexity of economic decisions has increased rapidly, thus highlighting the importance of developing and implementing sophisticated and efficient quantitative analysis techniques for supporting and aiding economic decision-making (Zavadskas, Turskis 2011). Multiple criteria decision making (MCDM) is an advanced field of operations research, provides decision- makers and analysts with a wide range of methodologies, which are overviewed and well suited to the complexity of economic decision problems (Hwang, Yoon 1981; Zopounidis, Doumpos 2002; Figueira et al. 2005). In this paper, we proposed a combined fuzzy AHP and COPRAS-G method approach to market segment evaluation and selection. The evaluation criteria for market segment evaluation and selection are based on McDonald and Dunbar's (2004) criteria list. According to these criteria, the required data utilized in the comparisons are collected from the related decision makers (DMs). After constructing the evaluation criteria hierarchy, the criteria weights are calculated by applying the fuzzy AHP method. Finally COPRAS-G method is employed to achieve the final ranking results. The detailed descriptions of the major steps are elaborated in the following subsections.

\section{Fuzzy AHP}

AHP is developed by Saaty (1980), maybe it is one of the famous, dazzling and most widely used models in decision making. With the extension of this method in fuzzy set theory, fuzzy AHP was developed. In the proposed methodology, AHP with its fuzzy extension, namely fuzzy AHP, is applied to obtain more decisive judgments by prioritizing the market segment selection criteria and weighting them in the presence of 
vagueness. There are numerous fuzzy AHP applications in the literature that propose systematic approaches for selection of alternatives and justification of problem by using fuzzy set theory and hierarchical structure analysis (Efendigil et al. 2008; Önüt et al. 2010). DMs usually find it more convenient to express interval judgments than fixed value judgments due to the fuzzy nature of the comparison process (Bozdag et al. 2003). This study concentrates on a fuzzy AHP approach introduced by Chang (1992), in which triangular fuzzy numbers are preferred for pairwise comparison scale. Extent analysis method is selected for the synthetic extent values of the pairwise comparisons. Some papers published used the fuzzy AHP procedure based on extent analysis method and showed how it can be applied to selection problems (Cebeci, Ruan 2007; Kahraman et al. 2003, 2004). The outlines of the fuzzy sets and extent analysis method for fuzzy AHP are given below.

A fuzzy number is a special fuzzy set $F=\left\{\left(x, \mu_{F}(x)\right), x \in R\right\}$, where $x$ takes its values on the real line, $R:-\infty \leq x \leq \infty$ and $\mu_{F}(x)$ is a continuous mapping from $R$ to the closed interval $[0,1]$. A triangular fuzzy number (TFN) expresses the relative strength of each pair of elements in the same hierarchy, mand can be denoted as $M=(l, m, u)$, where $l \leq$ $m \leq u$. The parameters $l, m, u$ indicate the smallest possible value, the most promising value, and the largest possible value respectively in a fuzzy event. The recent applications of fuzzy AHP method, in short, are listed below:

- Keršulienė and Turskis (2011) used fuzzy AHP and ARAS for architect selection.

- Fouladgar et al. (2011) used fuzzy AHP and fuzzy TOPSIS for prioritizing strategies of the Iranian mining sector.

- Lin et al. (2011) used fuzzy Delphi method, fuzzy AHP and fuzzy theory to develop an evaluation system of knowledge management performance.

- Nepal et al. (2010) used fuzzy AHP approach to prioritization of CS attributes in target planning for automotive product development.

- Heo et al. (2010) used fuzzy AHP for analysis of the assessment factors for renewable energy dissemination program evaluation.

- Haghighi et al. (2010) applied fuzzy AHP to e-banking development in Iran.

- Tiryaki and Ahlatcioglu (2009) used fuzzy AHP for Fuzzy portfolio selection.

- Gungor et al. (2009) used fuzzy AHP approach to personnel selection problem. Triangular type membership function of $\mathrm{M}$ fuzzy number can be described as in Equation 1 .

$$
\mu_{M}(x)=\left\{\begin{array}{cc}
0 & x \prec l \\
(x-l) /(m-l) & l \leq x \leq m \\
(u-x) /(u-m) & m \leq x \leq u \\
0 & x \succ u
\end{array} .\right.
$$

A linguistic variable is a variable whose values are expressed in linguistic terms (Önüt et al. 2008). The concept of a linguistic variable is very useful in dealing with situations, which are too complex or not well defined to be reasonably described in conventional quantitative expressions (Zadeh 1965; Zimmermann 1991; Kaufmann, Gupta 1991).

In this study, the linguistic variables that are utilized in the model can be expressed in positive TFNs for each criterion as in Figure 1. 


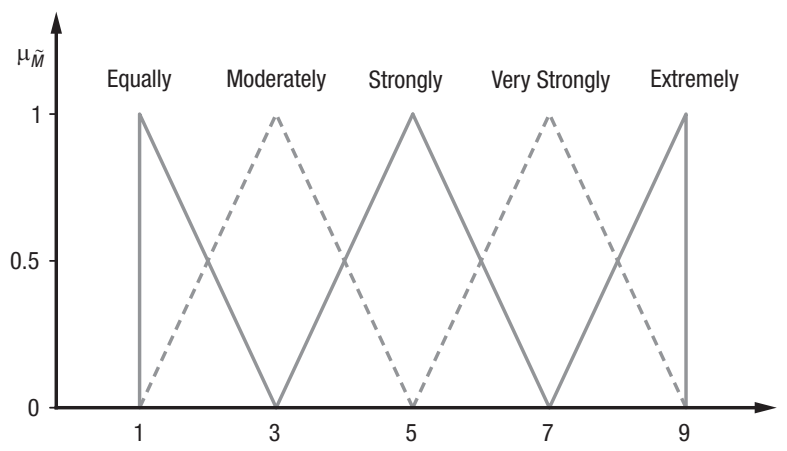

Fig. 1. Linguistic variables for the importance weight of each criterion

The linguistic variables matching TFNs and the corresponding membership functions are provided in Table 2. Proposed methodology employs a Likert Scale of fuzzy numbers starting from $\tilde{1}$ to $\tilde{9}$, symbolized with tilde $(\sim)$ for the fuzzy AHP approach. Table 2 depicts AHP and fuzzy AHP comparison scale considering the linguistic variables that describes the importance of criteria and alternatives to improve the scaling scheme for the judgment matrices.

Table 2. Linguistic variables describing weights of the criteria and values of ratings

\begin{tabular}{|c|c|c|c|c|}
\hline $\begin{array}{l}\text { Linguistic scale for } \\
\text { importance }\end{array}$ & $\begin{array}{l}\text { Fuzzy numbers } \\
\text { for fuzzy AHP }\end{array}$ & Membership function & Domain & $\begin{array}{c}\text { Triangular fuzzy } \\
\text { scale }(l, m, u)\end{array}$ \\
\hline Just equal & & & & $(1.0,1.0,1.0)$ \\
\hline Equal importance & $\tilde{1}$ & $\mu_{M}(x)=(3-x) /(3-1)$ & $1 \leq x \leq 3$ & $(1.0,1.0,3.0)$ \\
\hline \multirow[t]{2}{*}{$\begin{array}{l}\text { Weak importance } \\
\text { of one over another }\end{array}$} & $\tilde{3}$ & $\mu_{M}(x)=(x-1) /(3-1)$ & $1 \leq x \leq 3$ & $(1.0,3.0,5.0)$ \\
\hline & & $\mu_{M}(x)=(5-x) /(5-3)$ & $3 \leq x \leq 5$ & \\
\hline \multirow[t]{2}{*}{$\begin{array}{l}\text { Essential or strong } \\
\text { importance }\end{array}$} & $\tilde{5}$ & $\mu_{M}(x)=(x-3) /(5-3)$ & $3 \leq x \leq 5$ & $(3.0,5.0,7.0)$ \\
\hline & & $\mu_{M}(x)=(7-x) /(7-5)$ & $5 \leq x \leq 7$ & \\
\hline \multirow[t]{2}{*}{$\begin{array}{l}\text { Very strong } \\
\text { importance }\end{array}$} & $\tilde{7}$ & $\mu_{M}(x)=(x-5) /(7-5)$ & $5 \leq x \leq 7$ & $(5.0,7.0,9.0)$ \\
\hline & & $\mu_{M}(x)=(9-x) /(9-7)$ & $7 \leq x \leq 9$ & \\
\hline $\begin{array}{l}\text { Extremely } \\
\text { preferred }\end{array}$ & $\tilde{9}$ & $\mu_{M}(x)=(x-7) /(9-7)$ & $7 \leq x \leq 9$ & $(7.0,9.0,9.0)$ \\
\hline \multicolumn{3}{|c|}{$\begin{array}{l}\text { If factor } i \text { has one of the above numbers assigned } \\
\text { to it when compared to factor } j \text {, then } j \text { has the reciprocal } \\
\text { value when compared with } i\end{array}$} & \multicolumn{2}{|c|}{$\begin{array}{l}\text { Reciprocals of above } \\
M_{1^{-1}} \approx\left(1 / u_{1}, 1 / m_{1}, 1 / l_{1}\right)\end{array}$} \\
\hline
\end{tabular}

By using TFNs via pairwise comparison, the fuzzy judgment matrix $\tilde{A}\left(a_{i j}\right)$ can be expressed mathematically as in Equation 2: 


$$
\tilde{A}=\left\{\begin{array}{llllll}
1 & \tilde{a}_{12} & \tilde{a}_{13} & \ldots & \tilde{a}_{1(n-1)} & \tilde{a}_{1 n} \\
\tilde{a}_{21} & 1 & \tilde{a}_{23} & \ldots & \tilde{a}_{2(n-1)} & \tilde{a}_{2 n} \\
\vdots & \vdots & \vdots & \vdots & \vdots & \vdots \\
\vdots & \vdots & \vdots & \cdots & \vdots & \vdots \\
\tilde{a}_{(n-1) 1} & \tilde{a}_{(n-1) 2} & \tilde{a}_{(n-1) 3} & \cdots & 1 & \tilde{a}_{(n-1) n} \\
\tilde{a}_{n 1} & \tilde{a}_{n 2} & \tilde{a}_{n 3} & \cdots & \tilde{a}_{n(n-1)} & 1
\end{array} .\right.
$$

The judgment matrix $\tilde{A}$ is a $n \times n$ fuzzy matrix containing fuzzy numbers $\tilde{a}_{i j}$.

$$
\tilde{a}_{i j}=\left\{\begin{array}{l}
1, i=j \\
\tilde{1}, \tilde{3}, \tilde{5}, \tilde{7}, \tilde{9} \text { or } \cdots \tilde{1}^{-1}, \tilde{3}^{-1}, \tilde{5}^{-1}, \tilde{7}^{-1}, \tilde{9}^{-1}, i \neq j
\end{array}\right. \text {. }
$$

Let $X=\left\{x_{1}, x_{2}, \ldots, x_{n}\right\}$ be an object set, whereas $U=\left\{u_{1}, u_{2}, \ldots, u_{n}\right\}$ is a goal set. According to fuzzy extent analysis, the method can be performed with respect to each object for each corresponding goal, $g_{i}$, resulting in m extent analysis values for each object, given as $M_{g i}^{1}, M_{g i}^{2}, \ldots, M_{g i}^{n}, i=1,2, \ldots, n$ where all the $M_{g i}^{j}(j=1,2, \ldots, m)$ are TFNs representing the performance of the object $x_{i}$ with regard to each goal $u_{j}$. The steps of Chang's extent analysis (1992) can be detailed as follows (Kahraman et al. 2003, 2004; Bozbura 2007):

Step 1: The fuzzy synthetic extent value with respect to the $i$ th object is defined as:

$$
S_{i}=\sum_{j=1}^{m} M_{g i}^{j} \otimes\left[\sum_{i=1}^{n} \sum_{j=1}^{m} M_{g i}^{j}\right]^{-1} .
$$

To obtain $\sum_{j=1}^{m} M_{g i}^{j}$, perform the fuzzy addition operation $\mathrm{m}$ extent analysis such that operation $\mathrm{m}$ extent analysis values for a particular matrix will be as follows:

$$
\sum_{j=1}^{m} M_{g i}^{j}=\left(\sum_{j=1}^{m} l_{j}, \sum_{j=1}^{m} m_{j}, \sum_{j=1}^{m} u_{j}\right),
$$

then obtain $\left[\sum_{i=1}^{n} \sum_{j=1}^{m} M_{g i}^{j}\right]^{-1}$, perform the fuzzy addition operation of $M_{g i}^{j}(j=1,2, \ldots, m)$ values as shown below:

$$
\sum_{i=1}^{n} \sum_{j=1}^{m} M_{g i}^{j}=\left(\sum_{i=1}^{n} l_{i}, \sum_{i=1}^{n} m_{i}, \sum_{i=1}^{n} u_{i}\right)
$$

then compute the inverse of the vector in Equation 6 as follows:

$$
\left[\sum_{i=1}^{n} \sum_{j=1}^{m} M_{g i}^{j}\right]^{-1}=\left(\frac{1}{\sum_{i=1}^{n} u_{i}}, \frac{1}{\sum_{i=1}^{n} m_{i}}, \frac{1}{\sum_{i=1}^{n} l_{i}}\right) .
$$


Step 2: The degree of possibility of $M_{2} \geq M_{1}$ is defined as:

$$
V\left(M_{2} \geq M_{1}\right)=\sup \left[\min \left(\mu_{M_{1}}(x), \mu_{M_{2}}(y)\right)\right],
$$

and it can be equivalently expressed as follows:

$$
V\left(M_{2} \geq M_{1}\right)=\operatorname{hgt}\left(M_{1} \cap M_{2}\right)=\mu_{M_{2}}(d)=\left\{\begin{array}{l}
1, i f\left(m_{2} \geq m_{1}\right), \\
0, i f\left(l_{1} \geq u_{2}\right), \\
\frac{l_{1}-u_{2}}{\left(m_{2}-u_{2}\right)-\left(m_{1}-l_{1}\right)}, \text { otherwise, }
\end{array}\right.
$$

where $d$ is the ordinate of the highest intersection point $D$ between $\mu_{M_{1}}$ and $\mu_{M_{2}}$ (see Figure 2). To compare $M_{1}$ and $M_{2}$, both the values of $V\left(M_{1} \geq M_{2}\right)$ and $V\left(M_{2} \geq M_{1}\right)$ are required.

Step 3: The degree of possibility of a convex fuzzy number to be greater than $k$ convex fuzzy numbers $M_{i}(i=1,2, \ldots, k)$ can be defined by Equation 10 .

$$
\begin{aligned}
& V\left(M \geq M_{1}, M_{2}, \ldots, M_{K}\right)=V\left[M \geq M_{1}\right] \text { and }, V\left[M \geq M_{2}\right] \text { and } \ldots \text { and }, \\
& V\left[M \geq M_{k}\right]=\min \left(V\left[M \geq M_{i}\right], i=1,2, \ldots, k\right) .
\end{aligned}
$$

Assume that:

$$
d^{\prime}\left(A_{i}\right)=\min \left(S_{i} \geq S_{k}\right),
$$

where: $k=1,2, \ldots, n ; k \neq i$. Then, the weight vector is given by as in Equation 12:

$$
W^{\prime}=\left(d^{\prime}\left(A_{1}\right), d^{\prime}\left(A_{2}\right), \ldots, d^{\prime}\left(A_{n}\right)\right)^{T},
$$

Where $A_{i}(i=1,2, \ldots, n)$ has $n$ elements.

Step 4: The normalized weight vectors are defined as:

$$
W=\left(d\left(A_{1}\right), d\left(A_{2}\right), \ldots, d\left(A_{n}\right)\right)^{T},
$$

where $W$ is a non fuzzy number.

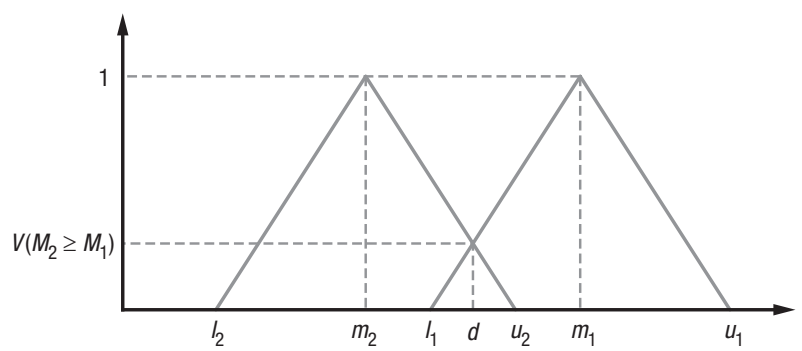

Fig. 2. Intersection point " $d$ " between two fuzzy numbers $M_{1}$ and $M_{2}$ 


\section{COPRAS-G METHOD}

In order to evaluate the overall efficiency of an alternative, it is necessary to identify selection criteria, to assess information relating to these criteria, and to develop methods for evaluating the criteria to meet the participant's needs. Decision analysis is concerned with the situation in which a decision-maker (DM) has to choose among several alternatives by considering a particular set of, usually conflicting criteria. For this reason Complex proportional assessment (COPRAS) method that was developed by Zavadskas and Kaklauskas (1996) can be applied. This method was applied to the solution of various problems in construction (Tupenaite et al. 2010; Ginevičius et al. 2008; Kaklauskas et al. 2010; Zavadskas et al. 2010). The most of alternatives under development always deal with vague future, and values of criteria cannot be expressed exactly. This MCDM problem should be determined not by exact criteria values, but by fuzzy values or by values in some intervals. Zavadskas et al. (2008) presented the main ideas of complex proportional assessment method with grey interval numbers (COPRAS-G) method. The idea of COPRAS-G method with criterion values expressed in intervals is based on the real conditions of decision making and applications of the Grey systems theory (Deng 1982; Deng 1988). The COPRAS-G method uses a stepwise ranking and evaluating procedure of the alternatives in terms of significance and utility degree.

The recent developments of decision making models based on COPRAS methods are listed below:

- Uzsilaityte and Martinaitis (2010) investigated and compared different alternatives for the renovation of buildings taking into account energy, economic and environmental criteria while evaluating impact of renovation measures during their life cycle;

- Chatterjee et al. (2011) presented materials selection model based on COPRAS and EVAMIX methods;

- Zavadskas et al. (2011) presented assessment of the indoor environment;

- Podvezko (2011) presented comparative analysis of MCDM methods (SAW and COPRAS);

- Hashemkhani Zolfani et al. (2011) presented forest roads locating using COPRASG method;

- Hashemkhani Zolfani et al. (2012) carried out research on quality control manager selection applying COPRAS-G method;

- Chatterjee and Chakraborty (2012) presented materials selection using COPRAS-G method.

The procedure of applying the COPRAS-G method consists of the following steps (Zavadskas et al. 2009):

1. Selecting the set of the most important criteria, describing the alternatives.

2. Constructing the decision-making matrix $\otimes X$ : 


$$
\begin{gathered}
\otimes X=\left[\begin{array}{cccc}
{\left[\otimes_{x_{11}}\right]} & \ldots & \ldots & {\left[\otimes_{x_{1 m}}\right]} \\
{\left[\otimes_{x_{21}}\right]} & \ldots & \ldots & {\left[\otimes_{x_{2 m}}\right]} \\
\vdots & \ldots & \ddots & \vdots \\
{\left[\otimes_{x_{n 1}}\right]} & \ldots & \ldots & {\left[\otimes_{x_{n m}}\right]}
\end{array}\right]=\left[\begin{array}{cccc}
{\left[\underline{x}_{11} ; \bar{x}_{11}\right]} & {\left[\underline{x}_{12} ; \bar{x}_{12}\right]} & \ldots & {\left[\underline{x}_{1 m} ; \bar{x}_{1 m}\right]} \\
{\left[\underline{x}_{21} ; \bar{x}_{21}\right]} & {\left[\underline{x}_{22} ; \bar{x}_{22}\right]} & \ldots & {\left[\underline{x}_{2 m} ; \bar{x}_{2 m}\right]} \\
\vdots & \vdots & \ddots & \vdots \\
{\left[\underline{x}_{n 1} ; \bar{x}_{n 1}\right]} & {\left[\underline{x}_{n 2} ; \bar{x}_{n 2}\right]} & \ldots & {\left[\underline{x}_{n m} ; \bar{x}_{n m}\right]}
\end{array}\right], \\
\quad j=\overline{1, n}, i=\overline{1, m}
\end{gathered}
$$

Here $\otimes x_{j i}$ is determined by $\otimes \bar{x}_{j i}$ (the smallest value, the lower limit) and $\bar{x}_{j i}$ (the biggest value, the upper limit).

3. Determining significances of the criteria $q_{i}$.

4. Normalizing the decision-making matrix $\otimes X$ :

$$
\underline{\tilde{x}}=\frac{\underline{x}_{j i}}{\frac{1}{2}\left(\sum_{j=1}^{n} \underline{x}_{j i}+\sum_{j=1}^{n} \bar{x}_{j i}\right)}=\frac{2 \underline{x}_{j i}}{\left(\sum_{j=1}^{n} \underline{x}_{j i}+\sum_{j=1}^{n} \bar{x}_{j i}\right)}, \overline{\tilde{x}}=\frac{\bar{x}_{j i}}{\frac{1}{2}\left(\sum_{j=1}^{n} \underline{x}_{j i}+\sum_{j=1}^{n} \bar{x}_{j i}\right)}=\frac{2 \bar{x}_{j i}}{\sum_{j=1}^{n}\left(\underline{x}_{j i}+\bar{x}_{j i}\right)} .
$$

In formula (15) $\underline{x}_{j i}$ is the lower value of the criterion $i$ in the alternative $j$ of the solution; $\bar{x}_{j i}$ is the upper value of the criterion $i$ in the alternative $j$ of the solution; $m$ is the number of criteria; $n$ is the number of the alternatives, compared. Then, the decisionmaking matrix is normalized:

$$
\otimes \tilde{X}=\left[\begin{array}{cccc}
{\left[\underline{\tilde{x}}_{11} ; \overline{\tilde{x}}_{11}\right]} & {\left[\underline{\tilde{x}}_{12} ; \overline{\tilde{x}}_{12}\right]} & \ldots & {\left[\underline{\tilde{x}}_{1 m} ; \overline{\tilde{x}}_{1 m}\right]} \\
{\left[\underline{\tilde{x}}_{21} ; \overline{\tilde{x}}_{21}\right]} & {\left[\underline{\underline{x}}_{22} ; \overline{\tilde{x}}_{22}\right]} & \cdots & {\left[\underline{\underline{x}}_{2 m} ; \overline{\tilde{x}}_{1 m}\right]} \\
\vdots & \ddots & \vdots \\
{\left[\underline{\underline{x}}_{n 1} ; \overline{\tilde{x}}_{n 1}\right]} & {\left[\underline{\underline{x}}_{n 2} ; \overline{\tilde{x}}_{n 2}\right]} & \ldots & {\left[\underline{\underline{x}}_{n m} ; \overline{\tilde{x}}_{n m}\right]}
\end{array}\right] .
$$

5. Calculating the weighted normalized decision matrix $\otimes \hat{X}$. The weighted normalized values $\otimes \hat{x}_{j i}$ are calculated as follows:

$$
\otimes \hat{x}_{j i}=\otimes \tilde{x}_{j i} \cdot q \text { or } \underline{\hat{x}}_{j i}=\underline{\tilde{x}}_{j i} \cdot q_{i} \text { and } \overline{\hat{x}}_{j i}=\overline{\tilde{x}}_{j i} \cdot q_{i},
$$

In formula (17), $q_{i}$ is the significance of the $i$-th criterion.

Then, the normalized decision-making matrix is:

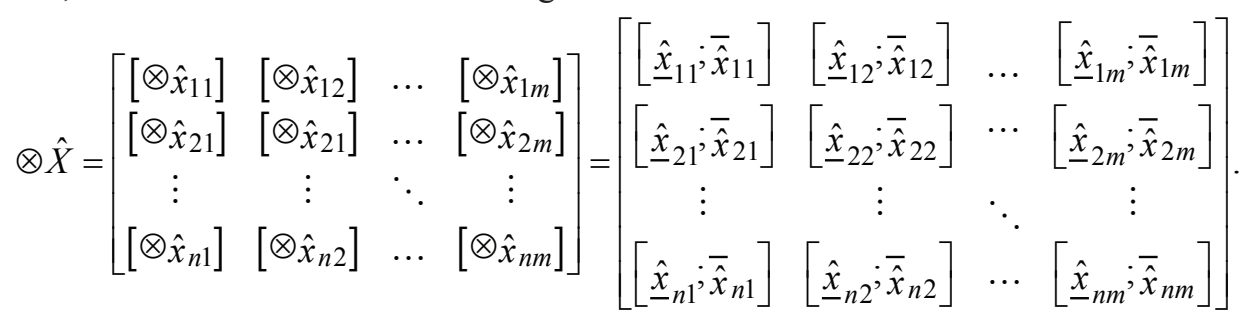


6. Calculating the sums $P_{j}$ of criterion values, whose larger values are more preferable:

$$
P_{j}=\frac{1}{2} \sum_{i=1}^{k}\left(\underline{\hat{x}}_{j i}+\overline{\hat{x}}_{j i}\right)
$$

7. Calculating the sums $R_{j}$ of criterion values, whose smaller values are more preferable:

$$
R_{j}=\frac{1}{2} \sum_{i=k+1}^{m}\left(\underline{\hat{x}}_{j i}+\overline{\hat{x}}_{j i}\right) ; i=\overline{k, m} .
$$

In formula (20), $(m-k)$ is the number of criteria which must be minimized.

8. Determining the minimal value of $R_{j}$ as follows:

$$
R_{\min }=\min _{j} R_{j} ; j=\overline{1, n} .
$$

9. Calculating the relative significance of each alternative $Q_{j}$ the expression is obtained:

$$
Q_{j}=P_{j}+\frac{\sum_{j=1}^{n} R_{j}}{R_{j} \sum_{j=1}^{n} \frac{1}{R_{j}}} .
$$

10. Determining the optimal criterion $K$ by the formula:

$$
K=\max _{j} Q_{j} ; j=\overline{1, n} .
$$

11. Determining the priority order of the alternatives.

12. Calculating the utility degree of each alternative by the formula:

$$
N_{j}=\frac{Q_{j}}{Q_{\max }} \times 100 \% .
$$

Here $Q_{j}$ and $Q_{\max }$ are the significances of the alternatives obtained from equation (22).

\section{Case study}

A real world case problem is selected in chair manufacturing company to illustrate the application of the proposed approach. The selected company is Nilper Company, which is one of the well-known brands in chair manufacturing industry in Iran. Nilper Company is a large- sized manufacturing enterprise, which is a recognized leader in chair manufacturing industry in Iran. Nilper Company currently offers more than 50 models of managerial, administrative, and clinical chairs based on customer needs and ergonomic standards. In recent years, there has been a steady growth in demand for many models of office chairs. Therefore, it was a matter of company's policy to undertake marketing research in order to improve its design process based on the main customers' wants for office chairs. Recently, this market research project was done and three segments were defined, which are denoted as SEG1, SEG 2 and SEG 3, respectively. Also, this company needs to evaluate and select obtained market segments for doing 
other marketing activities. Consequently, the project team including R\&D Manager, Marketing Manager, Sales Manager and two industrial engineers working for the company was constructed. At this point, the company needs to evaluate segments and select only one segment from them. So, the first criteria list based on McDonald and Dunbar (2004) for the market segment evaluation and selection was prepared. The number of criteria was very high and it was very difficult to evaluate all of them. So project team decided to choose some number of criteria for evaluating. Besides, they had to consider their company conditions, future plans, competitors, etc. For reducing the number of criteria and in order to select the most reasonable criteria, a questionnaire including all the first list criteria was designed. Then, the project team have been asked to give a rate to each of the criterion containing "not important at all", "not very important", "important", "quite important" and "very important" which are the verbal representation of the 1-5 numeric scale respectively. Next, rank of each criterion was selected based on the geometric mean of each criterion in all questionnaires. In the end and based on these ranks, nine criteria were determined to perform the analysis. The nine criteria are: Degree of concentration, Laws and government agency regulations, Types of competitors, Contribution margins, Manufacturing process technology required, Complexity, Growth rate per year, Size, and Leveraging factors which are denoted as $\mathrm{X}_{1}, \mathrm{X}_{2}, \mathrm{X}_{3}, \mathrm{X}_{4}, \mathrm{X}_{5}$, $\mathrm{X}_{6}, \mathrm{X}_{7}, \mathrm{X}_{8}$, and $\mathrm{X}_{9}$, respectively. Furthermore, project team decided about kind of each criterion based on situations of Iran market. After determining all selection criteria and alternatives, the paired comparisons for criteria list (see Table 3) were made by using the TFNs to tackle the ambiguities involved in the process of the linguistic assessment of the data. The project team filled this table, formed by reaching general agreement on questions related to the importance of the criteria and alternatives via Delphi technique as a group decision- making tool.

According to the weights in Table 3, Size, Growth rate per year and Types of competitor were three of the most important considered criteria.

\section{Results}

The aim of using fuzzy AHP is to determine importance weight of the criteria that will be employed in COPRAS-G method. Table 3 depicts the pairwise comparison matrix set by TFNs that matches linguistic statements of data. The fuzzy values of paired comparison were converted to crisp values via the Chang's extent analysis as mentioned before. First, the fuzzy synthetic extent values were calculated by using Equation 4 with the help of Equations 5-7. Equations 8-9 were applied to express the degree of synthetic extent values. To have a weight vector given by as in Equation12, Equations 10-11 were applied by comparing the fuzzy numbers. After normalizing weight vector defined as in Equation 13, the obtained priority weight vector of criteria is figured out in the last column of Table 3. After this stage, project team evaluated each segment according to each criterion and Table 4 was developed. 


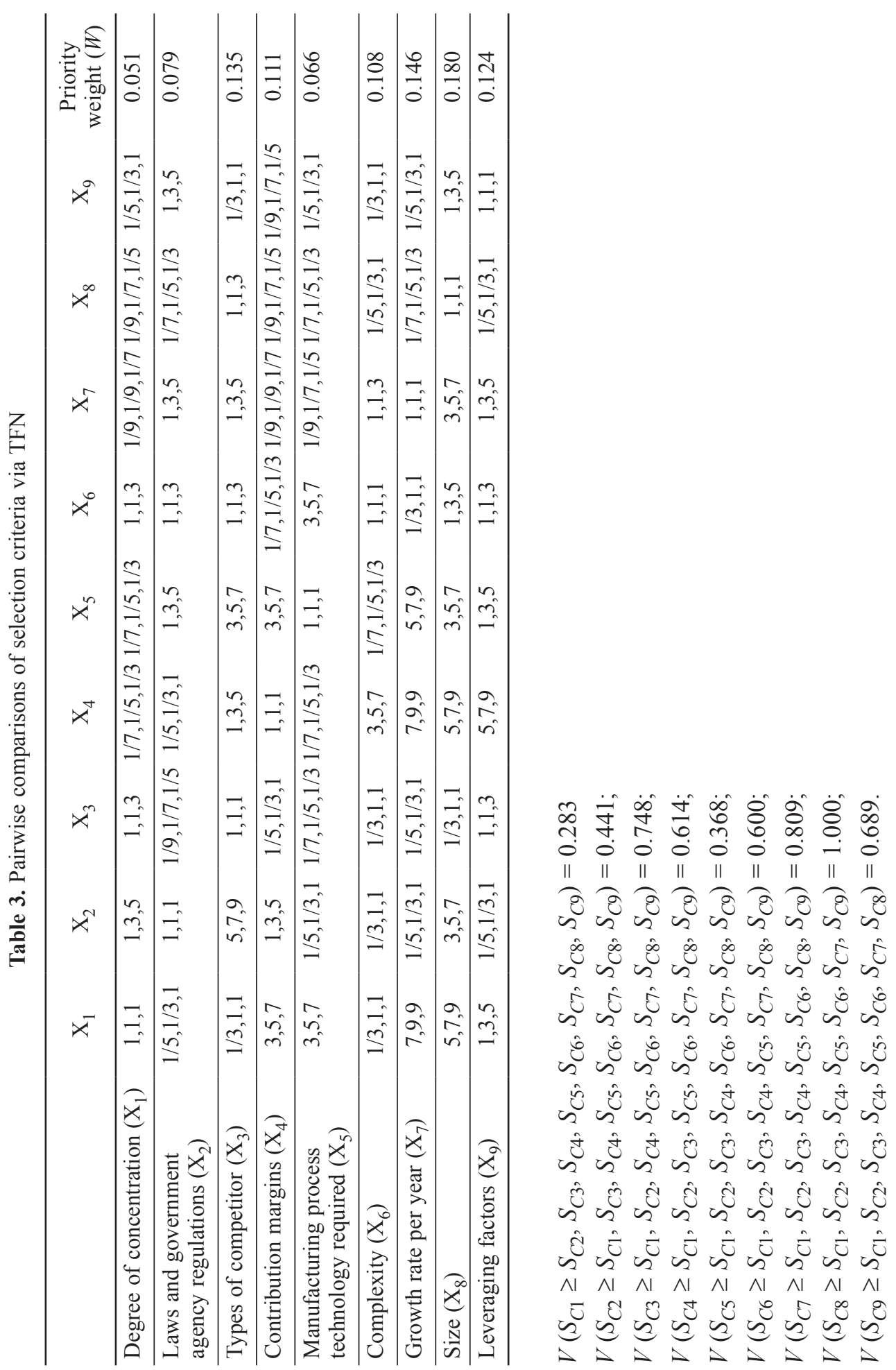


Table 4. Initial decision- making matrix with the criteria values described in intervals

\begin{tabular}{lccccccccc}
\hline & $\otimes x_{1}$ & $\otimes x_{2}$ & $\otimes x_{3}$ & $\otimes x_{4}$ & $\otimes x_{5}$ & $\otimes x_{6}$ & $\otimes x_{7}$ & $\otimes x_{8}$ & $\otimes x_{9}$ \\
\hline opt & Min & Min & Min & Max & Min & Min & Max & Max & Max \\
\hline$q_{i}$ & 0.051 & 0.079 & 0.135 & 0.111 & 0.066 & 0.108 & 0.146 & 0.180 & 0.124 \\
\hline \hline & $\underline{x_{1}}, \bar{x}_{1}$ & $\underline{x_{2}}, \bar{x}_{2}$ & $\underline{x_{3}}, \bar{x}_{3}$ & $\underline{x_{4}}, \bar{x}_{4}$ & $\underline{x_{5}}, \bar{x}_{5}$ & $\underline{x_{6}}, \bar{x}_{6}$ & $\underline{x_{7}}, \bar{x}_{7}$ & $\underline{x_{8}}, \bar{x}_{8}$ & $\underline{x_{9}}, \bar{x}_{9}$ \\
\hline \hline SEG 1 & 4060 & 4060 & 8090 & 7080 & 2030 & 6070 & 8090 & 6070 & 5060 \\
\hline SEG 2 & 7080 & 5060 & 6070 & 8090 & 4050 & 7080 & 9095 & 5060 & 6070 \\
\hline SEG 3 & 5060 & 7080 & 6070 & 6070 & 3040 & 6070 & 8090 & 7080 & 6070 \\
\hline
\end{tabular}

It indicates the initial decision making matrix, with the criterion values described in intervals. For the weight of criteria, we used weights of the last column of Table 3 . The initial decision making matrix has been normalized first as discussed in section COPRAS-G method. The normalized decision-making matrix is presented in Table 5.

Table 5. Normalized weighted decision making matrix

\begin{tabular}{|c|c|c|c|c|c|c|c|c|c|}
\hline & $\otimes \hat{x}_{1}$ & $\otimes \hat{x}_{2}$ & $\otimes \hat{x}_{3}$ & $\otimes \hat{x}_{4}$ & $K_{P}$ & $\otimes \hat{x}_{6}$ & $\otimes \hat{x}_{7}$ & $\otimes \hat{x}_{8}$ & $\otimes \hat{x}_{9}$ \\
\hline \multirow[t]{2}{*}{ Opt. } & Min & Min & Min & Max & Min & Min & Max & Max & Max \\
\hline & $\underline{x_{1}}, \bar{x}_{1}$ & $\underline{x_{2}}, \bar{x}_{2}$ & $\underline{x_{3}}, \bar{x}_{3}$ & $\underline{x_{4}}, \bar{x}_{4}$ & $\underline{x_{5}}, \bar{x}_{5}$ & $\underline{x_{6}}, \bar{x}_{6}$ & $x_{7}, \bar{x}_{7}$ & $\underline{x_{8}}, \bar{x}_{8}$ & $\underline{x_{9}}, \bar{x}_{9}$ \\
\hline SEG 1 & 0.0160 .019 & 0.0180 .02 & $\begin{array}{lll}0.051 & 0.057\end{array}$ & 0.0350 .04 & 0.0130 .01 & 0.0320 .03 & 0.0440 .05 & 0.0560 .065 & 0.0340 .041 \\
\hline SEG 2 & & 0.0220 .026 & $\begin{array}{lll}0.038 & 0.044\end{array}$ & 0.040 .045 & 0.0260 .032 & 0.0370 .043 & $\begin{array}{lll}0.05 & 0.052\end{array}$ & 0.0470 .056 & $\begin{array}{lll}0.041 & 0.047\end{array}$ \\
\hline SEG 3 & 0.0130 .016 & 0.0310 .036 & $\left|\begin{array}{lll}0.038 & 0.044\end{array}\right|$ & 0.030 .035 & 0.0190 .026 & $\begin{array}{lll}0.032 & 0.037\end{array}$ & $\begin{array}{llll}0.044 & 0.05\end{array}$ & 0.0650 .074 & $\begin{array}{lll}0.041 & 0.047\end{array}$ \\
\hline
\end{tabular}

Table 6 summarizes the results. The higher degree means the better rank, so based on the results of Table 6, the ranking of the three segments is "SEG 3>SEG $1>$ SEG 2".

Table 6. Evaluation of utility degree

\begin{tabular}{lcccc}
\hline \multicolumn{1}{c}{ Segment } & $P_{j}$ & $R_{j}$ & $Q_{j}$ & $N_{j}$ \\
\hline SEG 1 & 0.1825 & 0.1399 & 0.3359 & $98.52 \%$ \\
\hline SEG 2 & 0.189 & 0.154 & 0.3284 & $96.38 \%$ \\
\hline SEG 3 & 0.1937 & 0.146 & 0.3407 & $100 \%$ \\
\hline
\end{tabular}

$P_{j}$ hybrid approach results indicate that the best alternative with the highest degree is the best segment for doing marketing activities. So, based on the proposed methodology, SEG 3 could be selected as the best segment for the problem of market segment evaluation and selection in the Nilper manufacturing company. 


\section{Conclusion}

Market environment becomes more and more competitive and companies should make right decisions about marketing problems. One of the important problems is market segment evaluation and selection. Market segment evaluation and selection is a critical managerial marketing activity for all the companies. It helps a company choose its target segment or segments so that company can focus its competitive advantages, its resources, its opportunities and marketing strategies on effectively satisfying customers' needs and wants. In this paper, a hybrid MCDM methodology based on fuzzy AHP and COPRAS-G method for selecting the most suitable market segment was proposed. Fuzzy AHP is used to calculate the weight of each criterion, and COPRAS-G method is proposed to prioritize market segments from the best to the worst ones. This application has indicated that the model can be efficiently used in evaluating and selecting segments. Although the application of the model proposed in this study is specific to market segment evaluation and selection, it can also be used with slight modifications in decision-making process.

\section{Reference}

Aghdaie, M. H.; Hashemkhani Zolfani, S.; Rezaeinia, N.; Mehri-Tekmeh, J. 2011. A hybrid fuzzy MCDM approach for market segments evaluation and selection, in International Conference on Management and Service Science (MASS) 1-4. Wuhan: IEEE.

Baker, M. J. 1988. Marketing Strategy and Management. New York: Macmillan Education.

Beane, T. P.; Ennis, D. M. 1987. Market segmentation: a review, European Journal of Marketing 21(5): 20-42. http://dx.doi.org/10.1108/EUM0000000004695

Beik, L. L.; Buzby, S. L. 1973. Profitability analysis by market segment, Journal of Marketing 37: 48-53. http://dx.doi.org/10.2307/1249946

Bettman, J. R. 1971. The structure of consumer choice processes, Journal of Marketing Research 8: 465-471. http://dx.doi.org/10.2307/3150238

Bock, T.; Uncles, M. 2002. Taxonomy of differences between consumers for market segmentation, International Journal of Research in Marketing 19: 216-219.

http://dx.doi.org/10.1016/S0167-8116(02)00081-2

Bonoma, T.; Shapiro, B. P. 1983. Industrial Market Segmentation: A Nested Approach. Cambridge, MA: Marketing Science Institute. http://dx.doi.org/10.1016/j.eswa.2006.02.006

Bozbura, F. T.; Beskese, A.; Kahraman, C. 2007. Prioritization of human capital measurement indicators using fuzzy AHP, Expert Systems with Applications 32: 1100-1112.

http://dx.doi.org/10.1016/S0166-3615(03)00029-0

Bozdag, C. E.; Kahraman, C.; Ruan, D. 2003. Fuzzy group decision making for selection among computer integrated manufacturing systems, Computers in Industry 51(1): 13-29.

http://dx.doi.org/10.1016/S0166-3615(03)00029-0

Calentone, R. J.; Sawyer, A. G. 1978. The stability of benefit segments, Journal of Marketing Research 15(3): 395-404. http://dx.doi.org/10.2307/3150588

Cebeci, U.; Ruan, D. 2007. A Multi-Attribute comparison of Turkish quality consultants by Fuzzy AHP, International Journal of Information Technology \& Decision Making 6(1): 191-207. http://dx.doi.org/10.1142/S0219622007002423

Chang, D.-Y. 1992. Extent analysis and synthetic decision, Optimization Techniques and Applications 1: 352-355. 
Chatterjee, P.; Chakraborty, S. 2012. Material selection using preferential ranking methods, $M a-$ terials \& Design 35: 384-393. http://dx.doi.org/10.1016/j.matdes.2011.09.027

Chatterjee, P.; Athawale, V. M.; Chakraborty, S. 2011. Materials selection using complex proportional assessment and evaluation of mixed data methods, Materials \& Design 32(2): 851-860. http://dx.doi.org/10.1016/j.matdes.2010.07.010

Chaturvedi, A.; Carroll, J. D.; Green, P. E.; Rotondo, J. A. 1997. A feature-based approach to market segmentation via overlapping k-centroids clustering, Journal of Marketing Research 34: 370-377. http://dx.doi.org/10.2307/3151899

Chiu, C.-Y.; Chen, Y.-F.; Kuo, I.-T. K. 2009. An intelligent market segmentation system using k-means and particle swarm optimization, Expert Systems with Applications 36: 4558-4565. http://dx.doi.org/10.1016/j.eswa.2008.05.029

Christen, F. G. 1987. Richness: a Way to Evaluate Segmentation Systems. FL: Paper presented at the attitude research conference. West Palm Beach.

Deng, J. L. 1982. Control problems of Grey systems, Systems and Control Letters 1(5): 288-294. http://dx.doi.org/10.1016/S0167-6911(82)80025-X

Deng, J. L. 1988. Introduction to Grey system theory, Journal of Grey Theory 1: 1-24.

Eckrich, D. W. 1984. Benefits or problems as market segmentation bases: a comment, Journal of Advertising 2: 57-59.

Efendigil, T.; Önüt, S.; Kongar, E. 2008. A holistic approach for selecting a third-party reverse logistics provider in the presence of vagueness, Computers and Industrial Engineering 54(2): 269-287. http://dx.doi.org/10.1016/j.cie.2007.07.009

Elrod, T.; Winner, R. S. 1982. An empirical evaluation of aggregation approaches for developing market segments, Journal of Marketing 46: 65-74. http://dx.doi.org/10.2307/1251363

Figueira, J.; Greco, S.; Ehrgott, M. (Eds.). 2005. Multiple Criteria Decision Analysis: State of the Art Surveys. Springer.

Fouladgar, M. M.; Yazdani-Chamzini, A.; Zavadskas, E. K. 2011. An integrated model for prioritizing strategies of the Iranian mining sector, Technological and Economic Development of Economy 17(3): 459-483. http://dx.doi.org/10.3846/20294913.2011.603173

Frank, R. E.; Massy, W. F.; Wind, Y. 1972. Market Segmentation. Englewood Cliffs, NJ: Prentice Hall.

Ginevičius, R.; Podvezko, V.; Raslanas, S. 2008. Evaluating the alternative solutions of wall insulation by multicriteria methods, Journal of Civil Engineering and Management 14(4): 217-226. http://dx.doi.org/10.3846/1392-3730.2008.14.20

Green, P. E. 1977. A new approach to market segmentation, Business Horizons 20: 61-73. http://dx.doi.org/10.1016/0007-6813(77)90088-X

Gungor, Z.; Serhadlioglu, G.; Kesen, S. E. 2009. A fuzzy AHP approach to personnel selection problem, Applied Soft Computing 9: 641-646. http://dx.doi.org/10.1016/j.asoc.2008.09.003

Haghighi, M.; Divandari, A.; Keimasi, M. 2010. The impact of 3D e-readiness on e-banking development in Iran: a fuzzy AHP analysis, Expert Systems with Applications 37: 4084-4093. http://dx.doi.org/10.1016/j.eswa.2009.11.024

Hanafizadeh, P.; Mirzazadeh, M. 2011. Visualizing market segmentation using self-organizing maps and Fuzzy Delphi method-ADSL market of a telecommunication company, Expert Systems with Applications 38: 198-205. http://dx.doi.org/10.1016/j.eswa.2010.06.045

Hashemkhani Zolfani, S.; Rezaeiniya, N.; Zavadskas, E. K.; Turskis, Z. 2011. Forest roads locating based on AHP- COPRAS-G methods - an empirical study based on Iran, E D M: Ekonomie a Management 14(4): 6-21. 
Hashemkhani Zolfani, S.; Rezaeiniya, N.; Aghdaie, M. H.; Zavadskas, E. K. 2012. Quality control manager selection based on AHP-COPRAS-G methods: a case in Iran, Economska IstraživanjaEconomic Research 25(1): 88-104.

Heo, E.; Kim, J.; Boo, K. J. 2010. Analysis of the assessment factors for renewable energy dissemination program evaluation using fuzzy AHP, Renewable and Sustainable Energy Reviews 14: 2214-2220. http://dx.doi.org/10.1016/j.rser.2010.01.020

Hwang, C. L.; Yoon, K. 1981. Multiple attribute decision making: a state of the art survey, in Lecture Notes in Economics and Mathematical Systems. Berlin: Springer-Verlag. 186 p.

Jang, S. C.; Morrison, A. M.; O’Leary, J. T. 2002. Benefit segmentation of Japanese pleasure travelers to the USA and Canada: selecting target markets based on the profitability and risk of individual market segments, Tourism Management 23: 367-378.

http://dx.doi.org/10.1016/S0261-5177(01)00096-6

Kahraman, C.; Ruan, D.; Dögan, I. 2003. Fuzzy group decision making for facility location selection, Information Sciences 157: 135-153. http://dx.doi.org/10.1016/S0020-0255(03)00183-X

Kahraman, C.; Cebeci, U.; Ruan, D. 2004. Multi-attribute comparison of catering service companies using fuzzy AHP: the case of Turkey, International Journal of Production Economics 87: 171-184. http://dx.doi.org/10.1016/S0925-5273(03)00099-9

Kaklauskas, A.; Zavadskas, E. K.; Naimaviciene, J.; Krutinis, M.; Plakys, V.; Venskus, D. 2010. Model for a complex analysis of intelligent built environment, Automation in Construction 19(3): 326-340. http://dx.doi.org/10.1016/j.autcon.2009.12.006

Kaufmann, A.; Gupta, M. M. 1991. Introduction to Fuzzy Arithmetic: Theory and Applications. New York: Van Nostrand Reinhold.

Kazemzadeh, R. B.; Behzadian, M.; Aghdasi, M.; Albadvi, A. 2009. Integration of marketing research techniques into house of quality and product family design, International Journal of Advance Manufacturing Technology 41: 1019-1033. http://dx.doi.org/10.1007/s00170-008-1533-2

Kersuliene, V.; Turskis, Z. 2011. Integrated fuzzy multiple criteria decision making model for architect selection, Technological and Economic Development of Economy 17(4): 645-666. http://dx.doi.org/10.3846/20294913.2011.635718

Kotler, P. 1980. Marketing Management-Analysis, Planning, and Control. $4^{\text {th }}$ ed. Prentice-Hall. Kotler, P. 1988. Marketing Management. Englewood Cliffs, NJ: Prentice-Hall.

Kotler, P. 1999. Marketing Management: Analysis, Planning, Implementation, and Control. $10^{\text {th }}$ edition. Englewood Cliffs, NJ: Prentice-Hall, Inc.

Kotler, P.; Armstrong, G. 2003. Principles of Marketing. $10^{\text {th }}$ ed. Upper Saddle River, NJ: Prentice-Hall.

Kuo, R. J.; Ho, L. M.; Hu, C. M. 2002. Integration of self-organizing feature map and $K$-means algorithm for market segmentation, Computers and Operations Research 29: 1475-1493. http://dx.doi.org/10.1016/S0305-0548(01)00043-0

Lee, G.; Morrison, A. M.; O’Leary, J. T. 2006. The economic value portfolio matrix: a target market selection tool for destination marketing organizations, Tourism Management 27: 576-588. http://dx.doi.org/10.1016/j.tourman.2005.02.002

Lehmann, D. R.; Moore, W. L.; Elrod, T. 1982. The development of distinct choice process segments over time, Journal of Marketing 46: 48-59. http://dx.doi.org/10.2307/3203340

Lin, E.-K.; Chang, C.-C.; Lin, Y.-C. 2011. Structure development and performance evaluation of construction knowledge management system, Journal of Civil Engineering and Management 17(2): 184-196.

Loker, L.; Perdue, R. 1992. A benefit-based segmentation of a nonresident summer travel market, Journal of Travel Research 31(1): 30-35. http://dx.doi.org/10.1177/004728759203100107 
Loudon, D.; Della Bitta, A. J. 1984. Consumer Behavior. Concepts and Application. London: McGraw-Hill International Editions.

MacLachlan, D. L.; Johansson, J. 1981. Market segmentation with multivariate aid, Journal of Marketing 45: 74-84. http://dx.doi.org/10.2307/1251722

McDonald, M.; Dunbar, I. 2004. Market Segmentation How to Do It How to Profit from It. Elsevier Butterworth-Heinemann.

McQueen, J.; Miller, K. 1985. Target market selection of tourists: a comparison of approaches, Journal of Travel Research 24(1): 2-6. http://dx.doi.org/10.1177/004728758502400101

Morrison, D. G. 1973. Evaluating market segmentation studies: the properties of R2, Management Science 19(11): 1213-1221. http://dx.doi.org/10.1287/mnsc.19.11.1213

Morrison, A. M. 2002. Hospitality and Travel Marketing. Albany, New York: Delmar Thomson Learning.

Nepal, B.; Yadav, O. P.; Murat, A. 2010. A fuzzy-AHP approach to prioritization of CS attributes in target planning for automotive product development, Expert Systems with Applications 37: 6775-6786. http://dx.doi.org/10.1016/j.eswa.2010.03.048

Novak, T. P.; De Leeuw, J.; MacEvoy, B. 1992. Richness curves for evaluating market segmentation, Journal of Marketing Research 29: 254-267. http://dx.doi.org/10.2307/3172574

Önüt, S.; Efendigil, T.; Karar, S. S. 2010. A combined fuzzy MCDM approach for selecting shopping center site: an example from Istanbul, Turkey, Expert Systems with Applications 37: 1973-1980. http://dx.doi.org/10.1016/j.eswa.2009.06.080

Önüt, S.; Karar, S. S.; Efendigil, T. 2008. A hybrid fuzzy MCDM approach to machine tool selection, Journal of Intelligent Manufacturing 19: 443-453.

http://dx.doi.org/10.1007/s10845-008-0095-3

Ou, C.-W.; Chou, S.-Y.; Chang, Y.-H. 2009. Using a strategy-aligned fuzzy competitive analysis approach for market segment evaluation and selection, Expert Systems with Applications 36: 527-541. http://dx.doi.org/10.1016/j.eswa.2007.09.018

Podvezko, V. 2011. The comparative analysis of MCDA methods SAW and COPRAS, Inzinerine Ekonomika - Engineering Economics 22(2): 134-146.

Porter, M. E. 1980. Competitive Strategy: Techniques for Analyzing Industries and Competitors. New York: The Free Press.

Saaty, T. L. 1980. The Analytic Hierarchy Process. New York, NY: McGraw-Hill.

Sarabia, F. J. 1996. Model for market segments evaluation and selection, European Journal of Marketing 30(4): 58-74. http://dx.doi.org/10.1108/03090569610118830

Simkin, L.; Dibb, S. 1998. Prioritizing target markets, Marketing Intelligence and Planning 16(7): 407-417. http://dx.doi.org/10.1108/02634509810244417

Smith, W. 1956. Product differentiation and market segmentation as alternative marketing strategies, Journal of Marketing 21: 3-8. http://dx.doi.org/10.2307/1247695

Tiryaki, F; Ahlatcioglu, B. 2009. Fuzzy portfolio selection using fuzzy analytic hierarchy process, Information Sciences 179: 53-69. http://dx.doi.org/10.1016/j.ins.2008.07.023

Tupenaite, L.; Zavadskas, E. K.; Kaklauskas, A.; Turskis, Z.; Seniut, M. 2010. Multiple criteria assessment of alternatives for built and human environment renovation, Journal of Civil Engineering and Management 16(2): 257-266. http://dx.doi.org/10.3846/jcem.2010.30

Uzsilaityte, L.; Martinaitis, V. 2010. Search for optimal solution of public building renovation in terms of life cycle, Journal of Environmental Engineering and Landscape Management 18(2): 102-110. http://dx.doi.org/10.3846/jeelm.2010.12

Van Auken, S.; Lonial, S. C. 1984. Assessing mutual association between alternative market segmentation bases, Journal of Advertising 1: 11-16. 
Wedel, M.; Kamakura, W. 2000. Market Segmentation: Conceptual and Methodological Foundations. Norwell, MA: Kluwer Academic Publishing.

Weinstein, A. 1987. Market Segmentation. Chicago, IL: Probus.

Weinstein, A. 2004. Handbook of Market Segmentation Strategic Targeting for Business and Technology Firms. NY: Haworth Press.

Wildt, A. R. 1976. On evaluating market segmentation studies and the properties of R2, Management Science 22(8): 904-908. http://dx.doi.org/10.1287/mnsc.22.8.904

Wind, Y. 1978. Issues and advances in segmentation research, Journal of Marketing Research 15(3): 317-337. http://dx.doi.org/10.2307/3150580

Wind, Y., Thomas, R. J. 1994. Segmenting industrial markets, Advance in Business Marketing and Purchasing 6: 59-82.

Zadeh, L. A. 1965. Fuzzy sets, Information and Control 8: 338-353. http://dx.doi.org/10.1016/S0019-9958(65)90241-X

Zavadskas, E. K.; Kaklauskas, A. 1996. Determination of an efficient contractor by using the new method of multi criteria assessment, in D. A. Langford, A. Retik (Eds.). International Symposium for "The Organization and Management of Construction". Shaping Theory and Practice. Vol. 2: Managing the Construction Project and Managing Risk. CIB W 65; London, Weinheim, New York, Tokyo, Melbourne, Madras. London: E and FN SPON, 94-104,.

Zavadskas, E. K.; Kaklauskas, A.; Turskis, Z.; Tamosaitiene, J.; Kalibatas, D. 2011. Assessment of the indoor environment of dwelling houses by applying the COPRAS-G method: Lithuanian case study, Environmental Engineering and Management Journal 10(5): 637-647.

Zavadskas, E. K.; Kaklauskas, A.; Turskis, Z.; Tamosaitiene, J. 2009. Multi-attribute decisionmaking model by applying grey numbers, Informatica 20(2): 305-320.

Zavadskas, E. K.; Kaklauskas, A.; Turskis, Z.; Tamosaitiene, J. 2008. Selection of the effective dwelling house walls by applying attributes values determined at intervals, Journal of Civil Engineering and Management 14(2): 85-93. http://dx.doi.org/10.3846/1392-3730.2008.14.3

Zavadskas, E. K.; Turskis, Z. 2011. Multiple criteria decision making (MCDM) methods in economics: an overview, Technological and Economic Development of Economy 17(2): 397-427. http://dx.doi.org/10.3846/20294913.2011.593291

Zavadskas, E. K.; Turskis, Z.; Tamosaitiene, J. 2010. Risk assessment of construction projects, Journal of Civil Engineering and Management 16(1): 33-46.

http://dx.doi.org/10.3846/jcem.2010.03

Zimmermann, H. J. 1991. Fuzzy Set Theory and Its Applications. $2^{\text {nd }}$ ed London: Kluwer Academic Publishers.

Zopounidis, C.; Doumpos, M. 2002. Multi-criteria decision aid in financial decision making: methodologies and literature review, Journal of Multi-Criteria Decision Analysis 11: 167-186. http://dx.doi.org/10.1002/mcda.333 
Mohammad Hasan AGHDAIE was born in 1986 in Iran. In 2009 he received a Bachelor of Industrial Engineering - Industrial Production from Shomal University, in Amol. In 2011 he received a Master of Industrial Engineering - Productivity and System Management from Shomal University. His current research interests include Operations research, Decision analysis, Multiple Criteria Decision Analysis and their applications, especially market related decisions, Market segmentation, Marketing research and modeling, Market Design and Engineering, Data mining, Application of Fuzzy sets and systems, Creative Thinking and Problem Solving and Pricing. He has published some papers in journals and conference proceedings.

Sarfaraz HASHEMKHANI ZOLFANI got a BS in Industrial Management and MS in Industrial Engineering- Productivity and System Management from Shomal University of Amol, Iran. He was accepted in M.S. without national exam because he was ranked as the top student and regarding his good GPA in B.S. He is the author of more than 40 scientific papers in International Conferences and International Journals which were published, accepted or under reviewing. His research interests include Performance Evaluation, Strategic Management, Decision-making Theory, Supply Chain Management, (Fuzzy) Multi Criteria Decision Making and Marketing.

Edmundas Kazimieras ZAVADSKAS. Prof, Head of the Department of Construction Technology and Management at Vilnius Gediminas Technical University, Vilnius, Lithuania. He has a PhD in Building Structures (1973) and Dr Sc. (1987) in Building Technology and Management. He is a member of the Lithuanian and several foreign Academies of Sciences. He is Doctore Honoris Causa at Poznan, Saint-Petersburg, and Kiev universities as well as a member of international organizations; he has been a member of steering and programme committees at many international conferences. E. K. Zavadskas is a member of editorial boards of several research journals. He is the author and co-author of more than 400 papers and a number of monographs in Lithuanian, English, German and Russian. Research interests are: building technology and management, decision-making theory, automation in design and decision support systems. 